\title{
The Genetic Determination of Tendency to Cardiovascular Disease in the Two Bardet Biedl Syndrome Cases
}

İki Bardet Biedl Sendromlu Olgunun Kardiyovasküler Hastalık Yatkınlığının Genetik Olarak Belirlenmesi

\author{
Ayça TÖREL ERGÜR'1, Özkan ERGÜR², Ahmet ÖKTEM${ }^{3}$, Suzan AKYILDIZ
}

\author{
${ }^{1}$ Ufuk University, Faculty of Medicine, Department of Child Health and Diseases, Pediatric Endocrinology Unit, Ankara, Turkey \\ ${ }^{2}$ Atatürk Training and Research Hospital, Department of Ophthalmology, Ankara, Turkey \\ ${ }^{3}$ Ufuk University, Faculty of Medicine, Department of Child Health and Diseases, Ankara, Turkey \\ ${ }^{4}$ Atatürk Training and Research Hospital, Department of Molecular Genetics, Ankara, Turkey
}

\begin{abstract}
Bardet-Biedl syndrome (BBS) is a genetic autosomal recessive disorder, characterized by abdominal obesity, mental retardation, polydactyly, hypogonadism, retinal pigmentary retinopathy, and renal constitutional abnormalities or functional impairment. In syndromic cases with obesity such as BBS, possibility of myocardial infarction and thromboembolic events at early ages should be considered. In this study, polymorphisms on cardiovascular disease susceptibility genes were investigated in two Bardet-Biedl cases. In both cases, polymorphisms were detected on Factor V, Factor XIII, methylenetetrahydrofolate reductase (MTHRF), Plasminogen activator inhibitor-1 (PAI-1) (4G/5G), Glycoprotein Illa receptor (HPA-1), and Apoprotein-E3/3 genes. In conclusion, in syndromic cases, possibility of thromboembolic diseases and myocardial infarction at early ages should be kept in mind. Monitoring and prophylaxis may be life saving for these cases with genetic susceptibility especially during the conditions of dehydration, severe infection, and operation.
\end{abstract}

Key Words: Bardet-Biedl syndrome, Cardiovascular disease, Genetic susceptibility

\section{ÖZET}

Bardet-Biedl sendromu (BBS) abdominal obezite, mental retardasyon, polidaktili, hipogonadizm, retinal pigmenter retinopati ve böbreğin yapısal/işlevsel anomalileri ile karakterize otozomal resesif geçişli genetik bir bozukluktur. BBS gibi obezite ile giden sendromik olgularda miyokard infarktüsü ve tromboembolik olayların yaşamın erken döneminde gelişebileceği göz önünde bulundurulmalıdır. Bu çalışmada, BBS’li iki olguda kardiyovasküler hastalık yatkınlık gen polimorfizmlerinin varlığı araştırıldı. Her iki olguda da Faktör V, XIII, metilentetrahidrofolatredüktaz (MTHRF), plazminojen aktivator inhibitör 1 (PAl-1) (4G/5G), glikoprotein Illa reseptör (HPA-1), and Apoprotein-E3/3 gen polimorfizmleri saptandı. Sonuç olarak sendromik olgularda erken dönemde gelişebilecek tromboembolik hastalıklar ve miyokard infarktüsü yönünden dikkatli olmak gerekir. Genetik yatkınlık saptanan bu olguları özellikle dehidratasyon, şiddetli enfeksiyon ve ameliyat gibi risk durumlarında sıkı izlem ve proflaksi yaşam kurtarıcı olabilir.

Anahtar Sözcükler: Bardet-Biedl sendromu, Kardiyovasküler hastalık, Genetik yatkınlık

\section{INTRODUCTION}

Childhood obesity is a major factor for the metabolic syndrome and cardiovascular diseases. Obesity in early childhood further increases the risk of premature illnesses and early death (1). Baerdet- Biedl syndrome (BBS) is a genetic autosomal recessive disease characterized by obesity, mental retardation, postaxial polydactyly, retinitis pigmentosa, hypogonadism, and renal abnormalities (2). Our two cases with BBS associated syndromic obesity were diagnosed as early metabolic syndrome. Since, a classic metabolic syndrome characterized by phrothrombotic riskand proinflamatory states and obese children associated with metabolic syndrome may be under the risk of thromboembolic disease, cardiovascular and thromboembolic diseases should be genetically investigated in obese children. In this study, cardiovascular and thromboembolic diseases were genetically investigated in two cases of BBS associated with obesity and metabolic syndrome. 


\section{PATIENTS and METHODS}

Our two cases with BBS admitted to pediatric endocrinology department of our hospital for obesity. Both cases were evaluated in our department by a detailed physical examination, pubertal staging, and anthropometric evaluations (chronological age, height, weight, standing height (expressed as SD score), body mass index (BMl: weight $(\mathrm{kg}) /$ height (meters²). The pubertal development stage was assessed by the same pediatric endocrinologist using criteria of Tanner classification. In the physical examination, acanthosis nigrigans reflexing insulin resistance was noticed in each case. Clinical and laboratory characteristics of both cases are shown in Tables I, II.

The clinical diagnosis of metabolic syndrome was described as abnormal glucose homeostasis, impaired fasting glucose, fasting hyperinsulinemia, impaired glucose tolerance, hypertension, and dyslipidemia. Metabolic syndrome was defined as having more than 3 criterias. For homeostasis model assessment of insulin resistance (HOMA-IR) (fasting glucose (nmol/L) $x$ fasting insulin (miu/ml), a cut off value of 22.5 was used as index of insulin resistance $(2,3)$.

Atherogenic index of plasma (AIP) was calculated by $\log (T G /$ HDL-C), with TG and HDL-C expressed in molar concentrations, and evaluated as $\operatorname{AIP}<0,11$; low risk, $\operatorname{AIP}(0.11$ - 0.21); intermediate risk, AIP>0.21; increased risk (4).

The criteria of metabolic syndrome were defined according to modified WHO criteria (3).

According to $\mathrm{WHO}$ criteria, metabolic syndrome was defined as follows;

Obesity (BMl >95th percentile for age and sex)

Abnormal glucose homeostasis (fasting glucose ( $\geq 100 \mathrm{mg} / \mathrm{dl}$ ), fasting hyperinsulinemia (prepubertal $>15 \mathrm{mU} / \mathrm{L}$, pubertal $>30$ $\mathrm{mU} / \mathrm{L}$ ), impaired glucose tolerance (OGTT 120 min;200mg/ dl $>$ plasma glucose level $>$ or $=140 \mathrm{mg} / \mathrm{dl}$ ) bu kısım anlaşımıyor

Hypertension (systolic blood pressure >95th percentile for age and sex)

Dyslipidemia (triglycerides $<10$ years, $>102 \mathrm{mg} / \mathrm{dl}$; $>10$ years, $>136 \mathrm{mg} / \mathrm{dl}$; low LDL-cholesterol, <135 mg/dl; high totalcholesterol >95th percentile)

Our cases had at least 3 criterias related to metabolic syndrome. Parameters of the cases relevant to metabolic syndrome are summarized in Table II.

General appearances of the cases, their hands and feet operated for polydactyly are demonstrated in Figures 1, 2. Maculopathy observed in case 1 and retinitis pigmentosa in both cases are illustrated in Figure 3. In both cases,

Table I: Clinical characteristics of our cases with BBS.

\begin{tabular}{|c|c|c|}
\hline & Case 1 & Case 2 \\
\hline Age (year) & 17.9 & 11.7 \\
\hline Sex & Male & Male \\
\hline Height/percentile HsDs & $178 / 0.48$ & $142(25-50) /-1.59$ \\
\hline Weight (kg) & 105 & 67 \\
\hline BMI/RBMI (\%) & $35.51 / 159 \%$ & $32.73 / 176 \%$ \\
\hline Puberty & TV:6 and $8 \mathrm{ml}$; PSB:8 cm & both TV:2 ml; PSB:4 cm \\
\hline Polydactyly & All of the hands and feet & All of the hands and feet \\
\hline Acantosis nigrigans & Disseminated & Moderate \\
\hline Retinitis pigmentosa & $\begin{array}{l}\text { Disseminated hyperpigmented areas as bone } \\
\text { corpuscules in the peripheral region }\end{array}$ & $\begin{array}{l}\text { Disseminated hyperpigmented areas as bone } \\
\text { corpuscules in the peripheral region }\end{array}$ \\
\hline Maculopathy & $(+)$, pallor of optic disc & $(-)$ \\
\hline Hepatosteatosis & Grade 2 & none \\
\hline Mental retardation & IQ:35-49 & IQ:37-50 \\
\hline Urinary system findings & $\begin{array}{l}\text { Bilateral lobulation anomaly of kidneys, } \\
\text { pelvicaliceal ectasia of left kidney }\end{array}$ & $\begin{array}{l}\text { Grade } 2 \text { ectasia of collector tubules, lobulation } \\
\text { anomaly of right kidney }\end{array}$ \\
\hline Echocardiography & Normal & Normal \\
\hline Pituitary MRI & Level of pituitary gland $7 \mathrm{~mm}$ & $\begin{array}{l}\text { Level of pituitary gland } 2 \mathrm{~mm} \text {, sphenoid bone } \\
\text { lipoma }\end{array}$ \\
\hline
\end{tabular}


polymorphisms were detected on Factor V, Factor XIII, methylenetetrahydrofolate reductase (MTHRF), Plasminogen activator inhibitor-1 (PAl-1) (4G/5G), Glycoprotein Illa receptor (HPA-1), and Apoprotein-E3/3 genes, indicating susceptibility to cardiovascular diseases (Table III).

Informed consent was taken from all subjects.

\section{DISCUSSION}

Coronary artery disease and atherosclerosis can be seen at any age in the population and have a high mortality. Childhood obesity is a major risk factor especially for the metabolic syndrome and further cardiovascular diseases. About one third of obese children and adolescents exhibit features of early metabolic syndrome (5). Therefore, determining genetic risk factors is important in establishing treatment strategies of obesity at early ages. About $2-3 \%$ of "essential" obesity in pediatric age has endocrine or genetic origin. A smaller proportion of such cases accounts for some rare syndromes. Obesity, hypertension, diabetes mellitus, hyperhomocystinemia, and constitutional abnormalities observed in syndromic cases may cause early development of vascular diseases. One of these syndromes is Bardet-Biedl syndrome that has an autosomal recessive inheritence and multi-system involvement. Eight different loci have been identified on 2q31 (BBS5), 3p13 (BBS3), 4q27 (BBS7), 11 q13 (BBS1), 13q32 (BBS8), 15q22.3 (BBS4), 16q21 (BBS2) and 20p12 (BBS6) (6) for BBs. BBS leads to multiple handicaps (visual impairment, complication of obesity, renal failure, and endocrine dysfunction) (7). Recent discoveries have lead to the hypothesis that ciliary dysfunction is a mechanism underlying the pathogenesis of BBS $(8,9)$. In this syndrome, all these clinical features can be seen in only $40-45 \%$ of the cases. One study reported that children with BBS show clinical features of obesity in 90-95\%, mental retardation in $80-87 \%$, polydactyly in $70-74 \%$, and hypogonadism in $65-99 \%$ of cases (9). Obesity is one of the primary clinical features of BBS. The causes of obesity resulted from both pituitary and hypothalamic abnormalities $(10,11)$. Obesity usually begins in childhood and severity of obesity increases with age (12). Among the most common sequelae of childhood obesity are hypertension and dyslipidemia. We determined obesity and dyslipidemia in both of our cases. In such cases, a careful cardiovascular evaluation should be performed.

Impaired oral glucose tolerance test (OGTT) and diabetes mellitus are present in $32 \%$ of children with BBS. OGTT was performed for our cases and it revealed impaired glucose tolerance. We determined insulin resistance in case 1 and impaired glucose tolerance in case 2 (Table I). BBS and metabolic syndrome association is a common situation. On

Table II: Metabolic syndrome parameters of two cases with BBS.

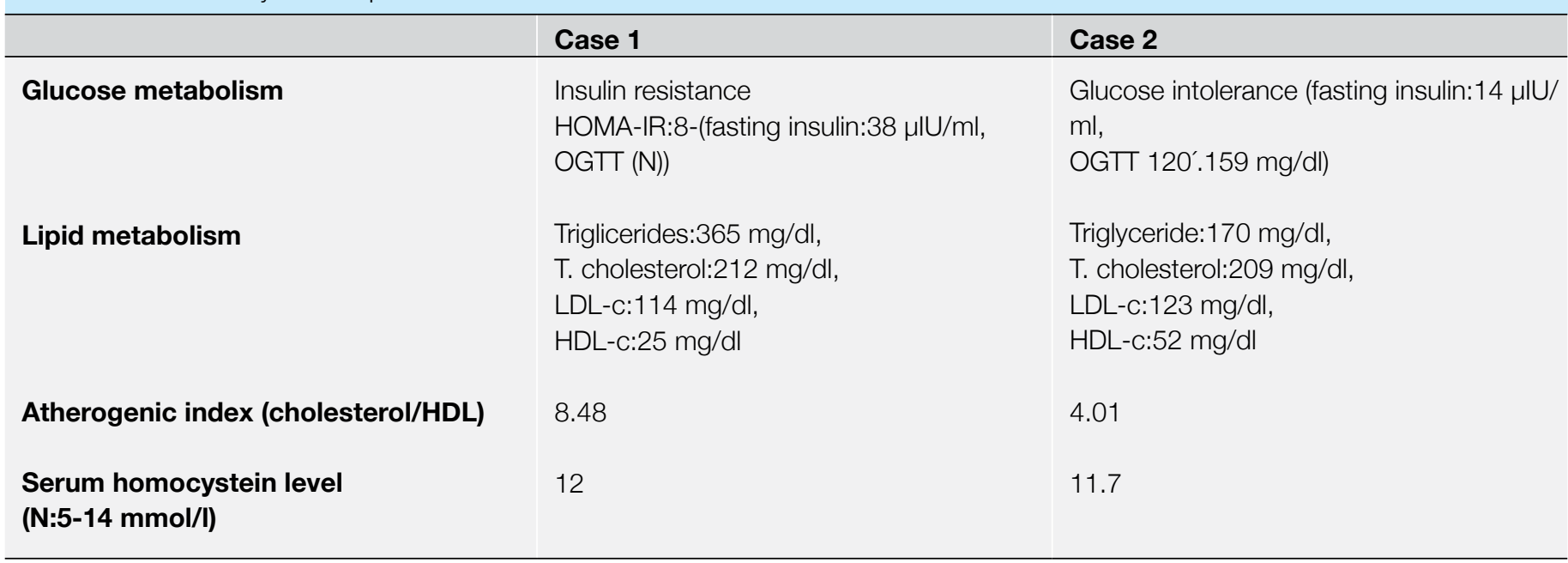

Table III: Polymorphisms detected on cardiovascular disease susceptibility genes of the cases.

\begin{tabular}{l|l|l}
\hline & Case 1 & Case 2 \\
\hline Factor XIII (V34L) & Heterozygous & Heterozygous \\
MTHFR (C677T) & Heterozygous & Homozygous \\
PAI & $4 \mathrm{G} / 5 \mathrm{G}$ & $4 \mathrm{G} / 5 \mathrm{G}$ \\
HPA-1 & $\mathrm{a} / \mathrm{a}$ & $\mathrm{a} / \mathrm{b}$ \\
Apo-E & $3 / 3$ & $3 / 3$ \\
\hline
\end{tabular}




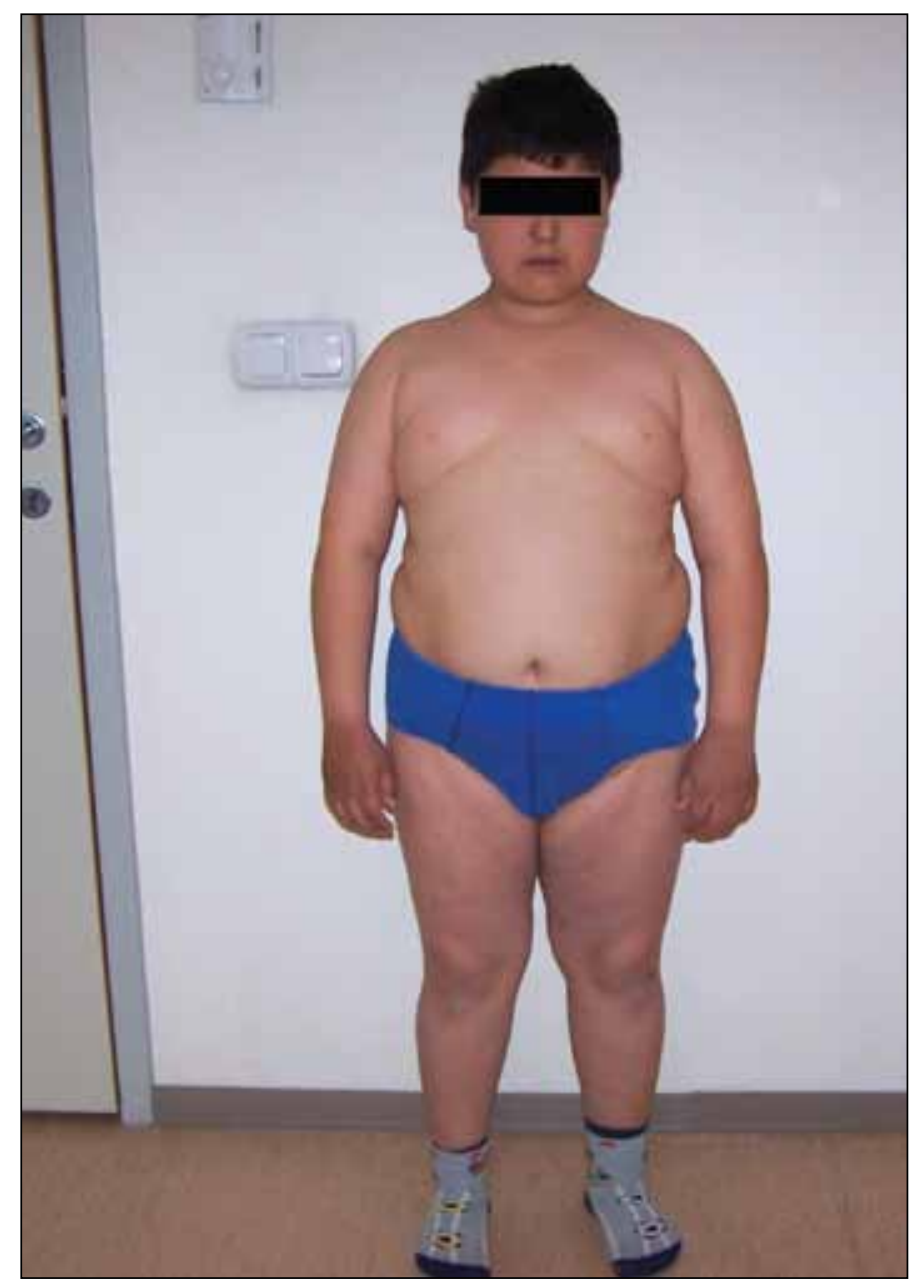

Figure 1: Photo of case 1.

the other hand, in literature, there were insufficient researches about BBS and metabolic syndrome association.

The ocular manifestations of BBS include an early and severe rod-cone dystrophia causing legal blindness in the second decade. Other ophthalmologic signs include nistagmus, myopia, optic atrophy, macular dystrophy, strabismus, and cataracts. Our cases had retinitis pigmentosa and macular dystrophy consistent with other reported articles.

In their autopsy study; McLoughlin and Shanklin reported that $69 \%$ of cases with BBS had cardiovascular disorder (13). Congenital cardiac abnormalities include atrial and ventricular septal defects and patent ductus arteriosus. We detected no cardiovascular abnormalities in transthoracic echocardiograms of our cases.

In cases with BBS, risk of cardiovascular disease is high because of damaged vascular structure, metabolic syndrome, prothrombotic, and proinflammatory states. Our two cases with BBS associated with syndromic obesity were diagnosed as metabolic syndrome. Classical metabolic syndrome is characterized by prothrombotic risk and proinflamatory states. In order to determine susceptibility to cardiovascular diseases in

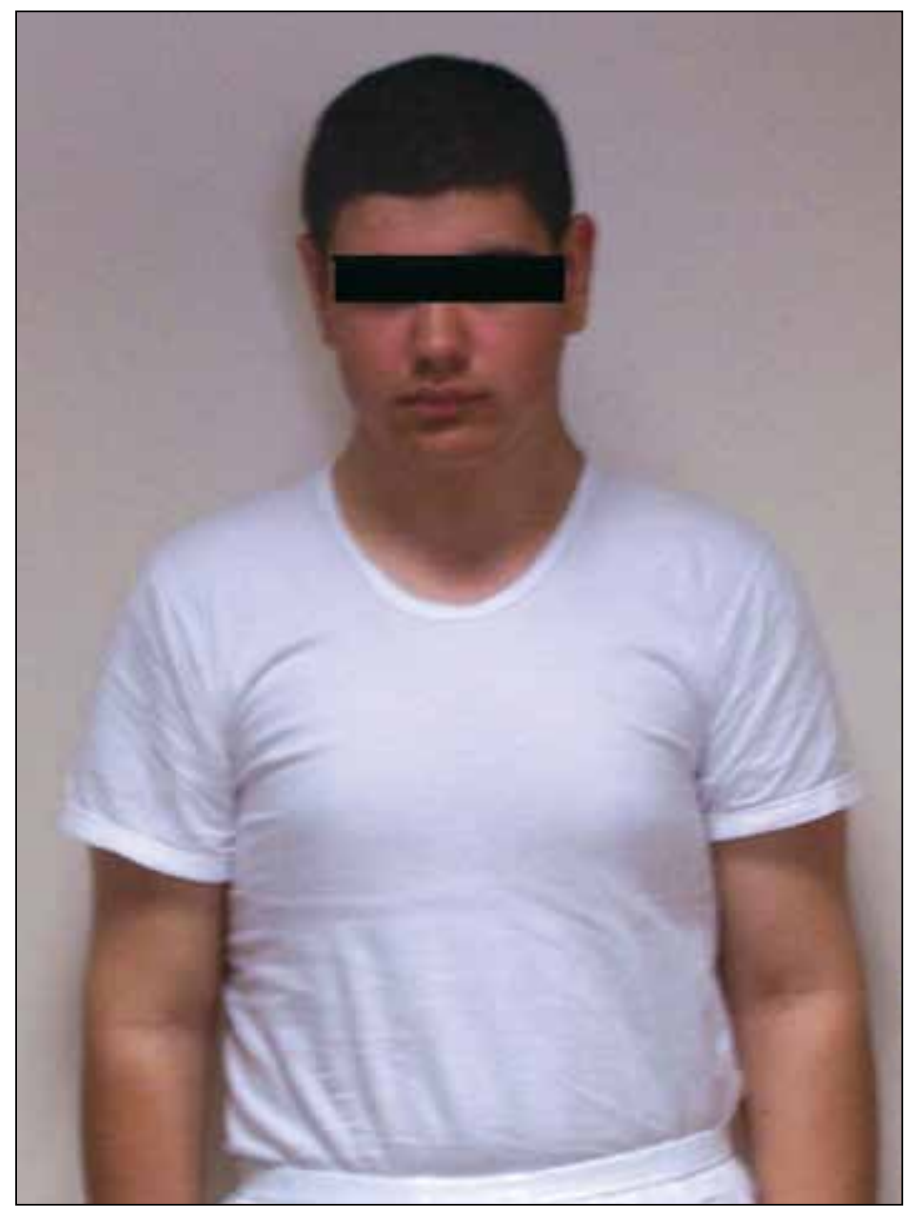

Figure 2: Photo of case 2.

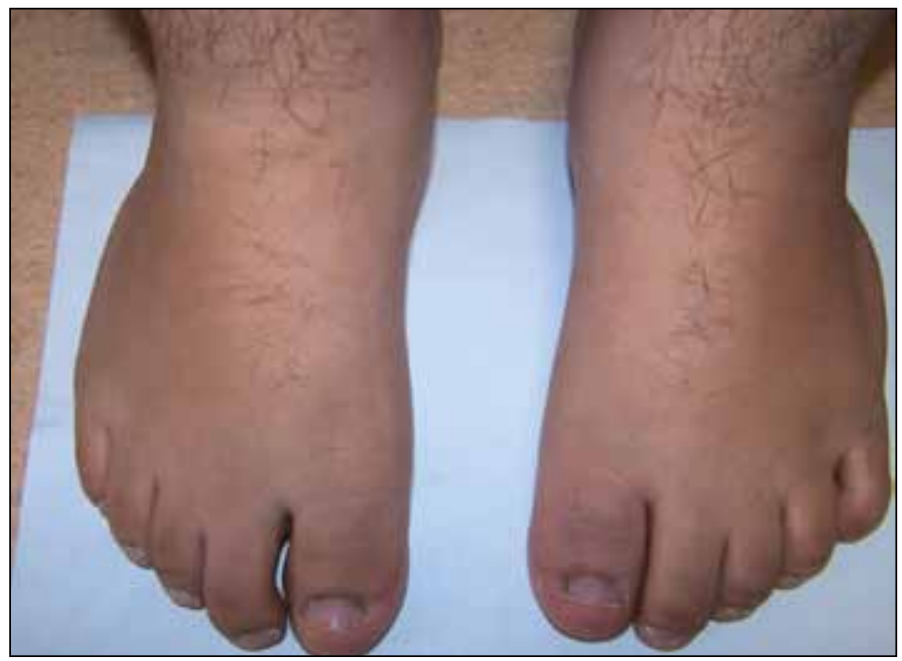

Figure 3: Feet of Case 2.

cases with metabolic syndrome, investigation of 12 cardiovascular disease (CVD) alleles (factor V, factor XIII, PAI-1, HPA-1, MTHRR C677T, Apo-B, Apo-E) could be usefull by reverse hybridization method. To investigate susceptibility to cardiovascular diseases of our cases diagnosed as BBS syndrome, polymorphisms of 12 CVD risk alleles were searched in their 
sera by reverse hybridization method (14). Methylenetetrahydrofolate reductase C677T (MTHFR C677T) variation leads to increase of plasma homocysteine concentration in individuals with low folic acid concentration. It was demonstrated that high homocysteine levels may increase the risk of thromboembolism and atherosclerosis (15). Heterozygous and homozygous mutations of MTHFR C677T were detected in our cases (Table III).

Deletion of guanosine in - 675 (4G-allele) position in the promoter site of plasminogen activator inhibitor (PAl) gene leads to an increase in blood concentration of PAl-1.

Heterozygous 4G-allele is associated with an increase in myocardial infarction risk. In the patients carriers of heterozygous $4 \mathrm{G}$ allele, the risk of vascular occlusion further increases if the patients are also carriers of Factor $V$ Leiden mutation (13).

Syndromic and nonsyndromic obesity is a metabolic disorder that is associated with increased plasminogen activator inhibitor-1 (PAl-1) concentration in the circulation. This increase is related to insulin resistance, dyslipidemia, and cardiovascular disease. Also some studies have demonstrated a relationship between plasma PAl-1 concentrations and $4 \mathrm{G} / 5 \mathrm{G}$ gene polymorphism on the PAl-1 gene while other studies have not (1). On the other hand, atherothrombotic complications in patients with insulin resistance and obesity are partly attributed to impaired fibrinolysis caused by increase in plasma levels of PAl-1 and $4 \mathrm{G} / 5 \mathrm{G}$ promoter polymorphism of the PAl-1 gene (13). In both of our cases, $4 G / 5 G$ heterozygous polymorphism was detected (Table III). In a study of performed in 2006, 134 nonsyndromic obese Turkish children were evaluated and the frequency of $4 \mathrm{G} / 4 \mathrm{G}$ genotype was more than $4 \mathrm{G} / 5 \mathrm{G}$ and $5 \mathrm{G} / 5 \mathrm{G}$ genotypes on the PAl-1 gene (1). The patients with $4 \mathrm{G} / 5 \mathrm{G}$ promoter polymorphism of the PAl- 1 gene can be at increased risk for devoloping vascular disease.

In people carrying Apo-E3/3 mutation, serum LDL-cholesterol level was high. Homozygous mutation is seen rarely in Apo. Heterozygous mutation also causes an increase in serum LDLcholesterol level (7). In our cases, Apo-E3/3 mutation and high serum LDL-cholesterol level were found.

Glycoprotein $\quad \mathrm{II}_{\mathrm{a}}$ is a fibrinogen receptor on the platelet membrane. Allele-a is defined as normal allele. Allele-b increases susceptibility to acute coronary events and myocardial infarction at early ages. Polymorphism in glycoprotein $\mathrm{II}_{\mathrm{a}}$ receptor (HPA-1) gene was also found in both cases.

In conclusion, childhood obesity is a major risk factor, especially for metabolic syndrome and further cardiovascular diseases. In syndromic cases of obesity such as Bardet-Biedl Syndrome, possibility of thromboembolic events at early ages should be kept in mind and necessary preventive measures should be taken. Genetic susceptibility for CVD is detected in syndromic cases with obesity, monitoring these patients may be life saving especially during the conditions of severe infection, dehydration, and operation.

\section{REFERENCES}

1. Berberoğlu M, Evliyaoğlu $O$, Adiyaman $P$, Ocal G, Ulukol B,Simsek $\mathrm{F}$, et al. Plasminogen activator inhibitor-1 (PAl-1)gene polymophism (-675 4G/5G) associated with obesity and vascular risk in children. J Pediatr Endocrinol Metab 2006;19;741-8.

2. Azari AA, Aleman TS, Cideciyan AV, Schwartz SB, Windsor EA, Sumaroka $A$, et al. Retinal disease expression in Bardet-Biedl syndrome-1 (BBS1) is a spectrum from maculopathy to retina-wide degeneration. Invest Ophthalmol Vis Sci 2006;47:5004-10.

3. Benzinou M, Walley A, Lobbens S, Charles MA, Jouret $B_{2}$ Fumeron $F$, et al. Bardet-Biedl syndrome gene variants are associated with both childhood and adult common obesity in French Caucasians. Diabetes 2006;55:2876-82.

4. Croft JB, Swift M. Obesity, hypertension, and renal disease in relatives of Bardet-Biedl syndrome sibs. Am J Med Genet 1990;36:37-42.

5. Nishimura DY, Swiderski RE, Searby CC, Berg EM, Ferguson AL, Hennekam R, et al. Comparative genomics and gene expression analysis identifies BBS9, a new Bardet-Biedl syndrome gene. Am J Hum Genet 2005;77:1021-33.

6. Heon E, Westall C, Carmi R, Elbedour K, Panton C,Mackeen L, et al. Ocular phenotypes of three genetic variants of Bardet-Biedl syndrome. Am J Med Genet A 2005;132A:283-7.

7. Dollfus $H$, Verloes A, Bonneau D, Cossee M, Perrin-Schmitt F, Brandt C, et al. Update on Bardet-Biedl syndrome. J Fr Ophtalmol 2005;28:106-12.

8. lannaccone A, Mykytyn K, Persico AM, Searby CC, Baldi A, Jablonski MM, et al. Clinical evidence of decreased olfaction in Bardet-Biedl syndrome caused by a deletion in the BBS4 gene. Am J Med Genet A 2005;132:343-6.

9. Fan Y, Rahman P, Peddle L, Hefferton D, Gladney N, Moore SJ, et al. Bardet-Biedl syndrome 1 genotype and obesity in the Newfoundland population. Int $\mathrm{J}$ Obes Relat Metab Disord 2004;28:680-4.

10. Grace C, Beales P, Summerbell C, Jebb SA, Wright A, Parker D, et al. Energy metabolism in Bardet-Biedl syndrome. Int J Obes Relat Metab Disord 2003;27:1319-24.

11. lannello S, Bosco P, Cavaleri A, Camuto M, Milazzo P, Belfiore F. A review of the literature of Bardet-Biedl disease and report of three cases associated with metabolic syndrome and diagnosed after the age of fifty. Obes Rev 2002;3:123-35.

12. Kiess W, Reich A, Muller G, Meyer K, Galler A, Bennek J,et al. Clinical aspects of obesity in childhood and adolescence-diagnosis, treatment and prevention. Int J Obes Relat Metab Disord 2001;25 Suppl 1:S75-9.

13. McLoughlin TG, Shanklin DR. Pathology of Laurence-Moon- Biedl Syndrome. J Pathol Bacteriol 1967;93:65-79.

14. Croft JB, Morrell D, Chase CL, Swift M. Obesity in heterozygous carriers of the gene for the Bardet-Biedl syndrome. Am J Med Genet 1995;2;55:12-5.

15. Elbedour K, Zucker N, Zalzstein E, Barki Y, Carmi R. Cardiac abnormalities in the Bardet-Biedl syndrome: Echocardiographic studies of 22 patients. Am J Med Genet 2000;90:80-1. 